\title{
Assessing gender roles in a changing landscape: diversified agro-pastoralism in drylands of West Pokot, Kenya
}

\author{
Vera N. Karmebäck ${ }^{1,5^{*}}$, John Ndung'u Wairore ${ }^{1,2}$, Magnus Jirström ${ }^{1,3}$ and Gert Nyberg ${ }^{1,4}$
}

\begin{abstract}
Previous studies in drylands have shown that while gender roles are becoming more flexible, privatization and formalization of land tenure tends to marginalize women in drylands while environmental degradation leads to differential changes in gender workload. Chepareria, a ward in West Pokot County, has undergone the abovementioned tenure and environmental changes and is nowadays dominated by private enclosures as a land management approach. This study reviewed in which ways these rangeland enclosures have influenced gender roles in the dryland systems of Chepareria in West Pokot, with specific regard to division of labour, financial responsibilities and decision-making processes on the household level, and also tries to identify the underlying driving forces that have contributed to the observed changes.

Our results indicate that the workload of women has increased under new land fragmentation processes in rangelands due to increased responsibilities in cattle herding and income generation, but also that due to this, women have gained higher influence in household decisions concerning the family economy. It was found that women to a larger extent than before are engaged in small-scale business such as the selling of farm products and poultry keeping, hence getting financial resources under their own control. In this way, women are involved in decision-making processes and income generation to a higher extent than before, though they are still excluded from certain traditionally male-dominated spheres both within and beyond the household, such as the sale of cattle and the handling of larger amounts of financial resources.

Under the new land fragmentation processes in Chepareria, women are increasingly seen as crucial income earners and they are enjoying a higher degree of financial independence, more decision-making power and a louder voice than before in household and public matters.
\end{abstract}

Keywords: Gender identity, Social transformation, Enclosure, Rangeland, Chepareria, Triple L Initiative

\section{Background}

Sustainable dryland development calls for an understanding of the gender-based roles, relations and obstacles that rural men and women face in drylands globally (FAO 2003). Studies by Verma (2001) and LastarriaCornhiel (1997) showed that women in rangelands do not automatically benefit when land tenure is formalized. According to Messer (2001), women tend to be marginalized by such changes in land ownership, which is

\footnotetext{
* Correspondence: verakarmeback@gmail.com

'Triple L Research Initiative - Land, Livestock and Livelihood Dynamics

(www.TripleL.se), Department of Forest Ecology and Management, Swedish

University of Agricultural Sciences, Umeå, Sweden

${ }^{5}$ Fröslövsvägen 543-16, 27176 Löderup, Sweden

Full list of author information is available at the end of the article
}

detrimental as previous studies by Westermann et al. (2005) have emphasized the importance of gender inclusivity in collective natural resource management (NRM) and conflict resolution. Traditionally, men have had the sole power of decision-making and planning of farm activities (FAO 2003; Nedessa et al. 2005). Under new land fragmentation processes in drylands, differential changes in the workload of men and women were observed (Flintan 2011). Overall, both men and women play pivotal roles in dryland development. It is in this regard that acknowledging and supporting these roles is crucial to sustainable management and development of natural resources.

Dryland degradation can lead to changes in gender roles (Awumbila and Momsen 1995; IFAD 2006). Studies 
in Asia and Africa have observed that environmental change usually has differentiated impact on men and women (FAO 2003; IFAD 2006). These impacts can lead to women assuming or taking on more work and responsibility (Awumbila and Momsen 1995). Overall, the magnitude and extent of these changes will vary geographically and across cultures. Though women are increasingly taking on more tasks and responsibilities in drylands due to dryland degradation and land restoration efforts (Awumbila and Momsen 1995), they tend to be excluded from most decision-making processes at both household and community levels (Nedessa et al. 2005). Although there exist limited sex- and agedisaggregated data on roles in rangeland/dryland management activities (FAO 2003), women are demanding more equality in access and control to land and participation in decision-making at various levels (IFAD 2006).

With increased land degradation in sub-Saharan Africa (SSA), rangeland enclosures have gained prominence as an effective and successful approach for the management of degraded rangelands within and beyond East Africa (Verdoodt et al. 2009; Mureithi et al. 2010). Enclosures refer to areas closed off from human and domestic animal interference for a specified duration of time in order to promote the natural regeneration of plants and reduce land degradation on formerly degraded communal grazing land (Mekuria et al. 2011). In Chepareria, enclosures were mainly established to address land degradation and provide stable grazing lands for the local pastoral community (Makokha et al. 1999; Kitalyi et al. 2002). Studies on the benefits derived from rehabilitating degraded rangelands in private enclosures in Chepareria not only underscored the role of enclosures in dryland restoration and management of pastoral rangelands but also indicated the changing gender roles with the establishment of private enclosures (Karmebäck 2015; Wairore et al. 2015a, b).

The increased use of enclosures as a land management tool in SSA is by some seen as a 'default' development in semi-arid areas (Woodhouse 2003). It is seen as a sustainable intensification of rangelands driving the systems towards more market-driven agro-pastoral systems (Catley et al. 2013; Woodhouse 2003; McDermott et al. 2010; Angassa and Oba 2010; Verdoodt et al. 2010). However, this development also generates considerable critique as it is argued to erode traditional values and lifestyles as well as eroding collective property rights and thereby generating land and water conflicts (Woodhouse 2003; Beyene 2009; Beyene 2010; Angassa and Oba 2008; Lesorogol 2008; Napier and Desta 2011).

Due to the role of gender relations in poverty alleviation and restoration of degraded rangelands, various studies have reiterated the need for further studies on the implications of enclosure establishment on gender relations among pastoral and agro-pastoral communities (Nedessa et al. 2005; Said et al. 2014). The County Government of West Pokot in its County Integrated Development Plan (CIDP) 2013 to 2017 identifies gender inequality as a major challenge in the county, reiterating that most women are confined to household/domestic chores and are mostly not involved in decision-making committees (County Government of West Pokot 2013).

In Chepareria, land ownership and environmental change due to rangeland enclosures are forcing people to adapt to these new environments, and consequently, these adaptive actions are prompting changes in gender roles at the household level. However, there exist limited information on the implications of rangeland enclosures on gender roles, responsibilities and decision-making power in the management and utilization of private enclosures as observed by Nedessa et al. (2005). The main objective of this study is to document the changing gender roles associated with changes in land use, environmental management and socio-economic status since the inception of rangeland enclosures as a land management approach to address land degradation in Chepareria drylands. This information will not only inform the upscaling of rangeland enclosures but will also be instrumental in sustainable management of enclosed areas given the importance of gender in agriculture, NRM and livelihood security amongst dryland communities.

\section{Study area}

The Pokot community is the dominant tribe in the study area. Though originally a pastoral community, they have diversified into other forms of production to meet livelihood needs, as will be discussed throughout this paper. Chepareria ward where the data for this study was collected is located centrally in West Pokot County in north-western Kenya. The ward incorporates areas that are predominantly pastoral in the north, mixed farming areas in the south and predominantly agro-pastoral areas in the centre, making up the largest livelihood area of the ward (see Fig. 1). The area has gently undulating plains surrounded by mountain ranges, and there is a great variation in rainfall received (total amount and distribution) as well as in temperatures, typical of semi-arid lands in sub-Saharan Africa. The rains are bimodal with the long rains from March to May and the short rains from mid-August to early November (NDMA 2014). According to the Kenya National Bureau of Statistics (KNBS), the population of Chepareria ward stood at 41,563 persons in 2009 (KNBS 2009).

\section{Methods}

The research presented here is part of a larger multidisciplinary research programme, the Triple L Initiative (Land, Livestock and Livelihood Dynamics in Dryland 


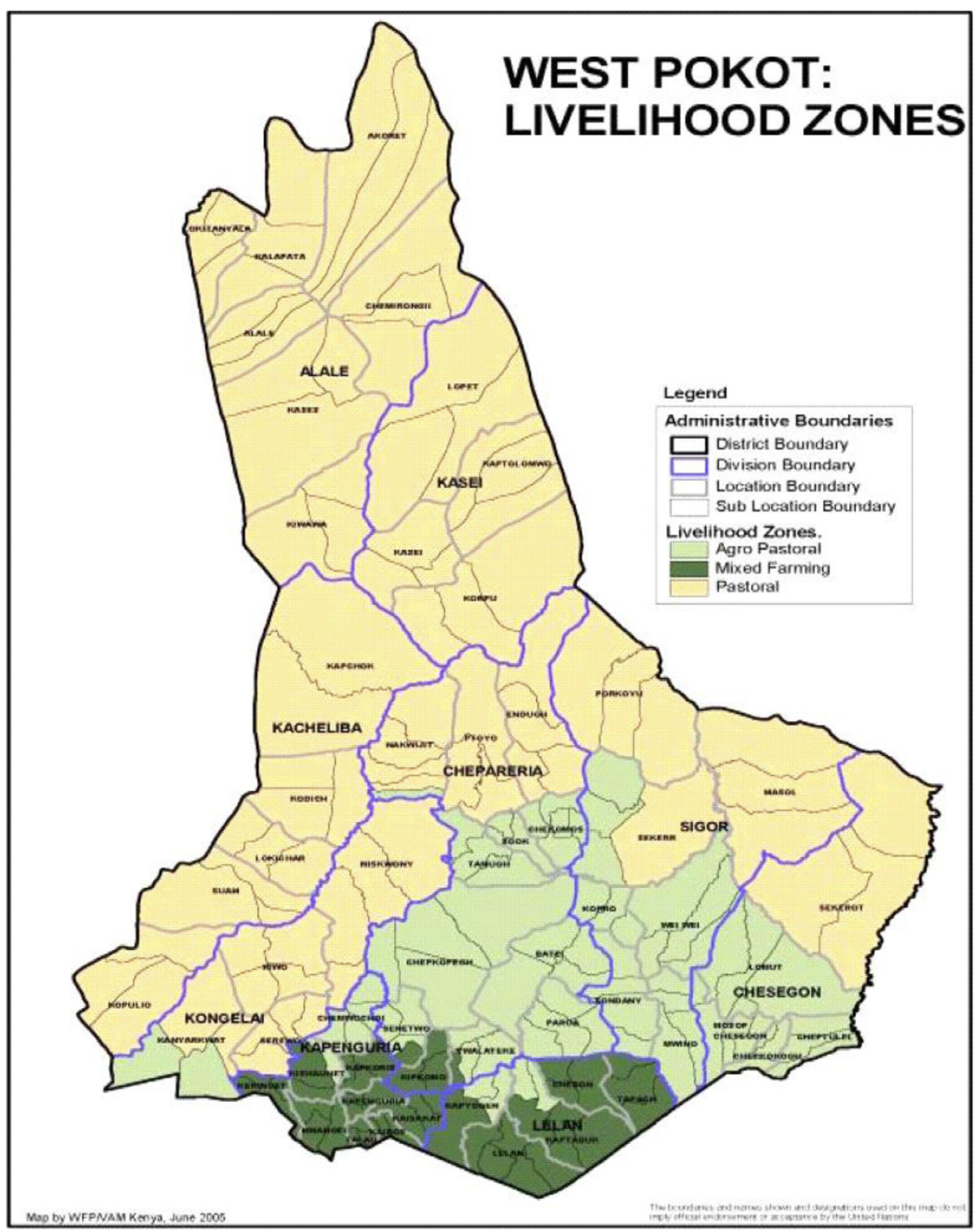

Fig. 1 West Pokot livelihood zones (WFPNAM Kenya, 2005) 
Systems, West Pokot, Kenya, www.TripleL.se). The Triple L Initiative seeks to study, analyse and understand the driving forces, processes, consequences and livelihood and food security outcomes of the transition from nomadic pastoralism to sedentary, livestock-based agropastoralism occurring in West Pokot County in northwestern Kenya and relate them to other areas with similar livelihood and land use issues. The initiative involves a highly multidisciplinary research team drawn from the biophysical and social sciences.

The aspect of Triple L presented here draws from two comparative studies of the Pokot community in Chepareria on narratives of shifts in gender roles in the context of the changing environmental and socioeconomic circumstances.

The two studies draw on data from multiple methods, including key informant interviews (KIIs) with knowledgeable individuals, interviews with individual household members (referred to here as HHIs - household interviews) and local history interviews through focus group discussions (FGDs) with both men and women, focusing on enclosure management and gender roles. A total of ten HHIs, eight FGDs and eight KIIs were undertaken in Chepareria. The size of the FGDs ranged from five to seven participants, and they were separated into male and female groups in order to get the different sexes' perception of how roles and responsibilities had changed with time. All respondents from FGDs and HIIs were however asked the same questions, no matter the gender, and hence also gave a perspective on the opposite gender. Informal discussions with the residents of Chepareria ward were also conducted. In addition, semistructured questionnaires with a random sample of 40 Chepareria households from four locations were conducted. The questionnaires incorporated questions about enclosure utilization and management, as well as changing gender roles with the establishment of enclosures. Furthermore, a literature review of secondary data was conducted to provide the context and framework for this research.

Unlike many local gender studies, which focus exclusively on decision-making, participation and empowerment challenges of women in drylands with the formalization of land tenure or changing dryland environments due to factors such as land degradation and desertification, this research intentionally elaborated the ways in which gender roles have changed with the establishment of enclosures in Chepareria, West Pokot. In taking this approach, gender roles are not treated as static but rather as a dynamic element that impacts and is impacted by broader cultural practices.

\section{Results and discussion}

Enclosures as drivers of change

Traditionally, the Pokot are a pastoralist and seminomadic community, and it was - and in certain, more remote parts of West Pokot still is - common to migrate with the animals across the border into Uganda in search of pasture. The men left with the satellite herd, and during these periods, women were left tending for the children and looking after the nucleus herd. They also cultivated sorghum and millet on small plots. Today, the Cheparerian community is predominantly agro-pastoral,practising livestock-keeping and rain-fed agriculture (Awino Ochieng and Karmebäck 2014b). Increasing population pressure, drought and insecurity augmented by government policies favouring sedentary lifestyles (land and social developments) confined and restricted pastoral mobility. With the establishment of enclosures, individuals owned and could properly manage the land. Results were recorded to be increased pastures availability, dry season grazing reserves and more reproductive and healthier animals for enclosure owners (Makokha et al. 1999). Consequently, as more individuals enclosed land, there was reduced pastoral migration (Makokha et al. 1999). Men were therefore free of their traditional role of herding, as animals only needed to be left to graze in the enclosure, taken to the river and back. Women on the other hand had more animals to milk, more productive land to tend and school-going children to attend to in addition to their domestic tasks. Overall - as this article will show - participation, decisionmaking and tasks of both men and women in Chepareria have changed over the years with these developments.

\section{Gendered division of labour and income generation}

Since primary education became free and compulsory in Kenya in 2003, formal education has become more accessible to Pokot children. This has led to changes in the household economy, caused by the connected schooling costs and other monetary requirements- because, even if primary education has officially been provided free of charge since 2003 in Kenya, several monetary needs arise when sending a child to school, such as for books, uniforms and other expenses. Several female respondents saw the increase in primary schooling as a contributing factor to why women have become increasingly involved in the monetary economy, as they are present in the household and therefore often the ones the young children turn to for small monetary needs. These petty household needs are not ranked as necessitating the sale of sheep and goats by the male household head. Consequently, women have to plan, prepare and invest adequately for these expenses. It is therefore not surprising to find women parading roasted maize, bananas, avocadoes, mangoes and sugarcane for sale on the KapenguriaKainuk roadside in Chepareria. The same applies to milk at dusk and in the early mornings. The surplus of these agricultural products has only been readily available locally since the people of Chepareria started enclosing their 
land, which led to an increase in the growing of fruits and vegetables, as well as to increased milk production, as there was pasture available all year round. In connection to this, the nutritional variety and the number of meals per day have also increased with time (Awino Ochieng and Karmebäck 2014a, b).

In total, there is more money moving in the Cheparerian community than before, and expenses have to be met, which is why the woman is increasingly seen too as a crucial income earner. These small entrepreneurial activities are breaking down the traditional boundary of the woman's place being in the home. With the income generated from the above-mentioned income-generating activities, wives enjoy a higher degree of independence. All of this has, in the opinion of most female respondents, furthermore led to a woman now being more entitled to criticize her husband if money is not well spent. Interesting to note here is also that female respondents pointed out that institutions like secondary schools have created a market locally, as there are outside people employed as teachers there (Karmebäck 2015). These are people who come from other parts of Kenya and live off a salary and normally do not own their own cattle or land to farm. Hence, they need to buy all daily items such as firewood, milk, eggs, vegetables and other foods. Female respondents pointed out that this creation of a local market had increased their entrepreneurial activities, as they now have a reliable point of sale. In line with Wernersson's (2013) findings, it is evident that cattle - the livestock that produces the largest monetary income - is still mainly a male space, even though many male as well as female respondents noted that they increasingly shared information and decisions on cattle sales between husband and wife. On the whole, the women's responsibilities however largely remain with the smaller incomegenerating activities.

In addition to their general household chores and entrepreneurial activities, most women are now furthermore expected to graze and water animals as more men engage in other income-generating activities such as livestock trading and shopkeeping (Karmebäck 2015). This trend was observed as early as two decades ago, when according to Makokha et al. (1999), 38\% of Cheparerians agreed then that women herding and watering livestock is one of the observed changes in the responsibility of family members. This percentage has however increased tremendously since then, as almost all female respondents interviewed for this study reported that grazing and watering the animals was now one of their daily tasks.

As mentioned above, the establishment of enclosures has facilitated the adoption of crop cultivation, particularly in areas where rain-fed agriculture is a possibility. By laying the foundation for beneficial interventions such as climate-smart agriculture, enclosures facilitate increased yield stability amongst private enclosure owners (Wairore 2015). This, coupled with the increased commercialization of agriculture in Chepareria has seen a shift towards more intensified and market-oriented production, especially in the wetter areas of Chepareria. Though the average cropped area in enclosures seems not to have changed but remained stable at around 1 ha (Makokha et al. 1999; Wairore et al. 2015a), land subdivision has reduced the average farm size from 13.9 ha in 1999 (Makokha et al. 1999) to approximately 5 ha in 2014, based on a study of 120 households in Chepareria ward (Wairore et al. 2015a). While crop cultivation used to be a duty of women, the notable increase in cropped area (as proportion of land) nowadays also engages the men. Besides the intensification in crop production, particularly in the wetter areas of the ward, the involvement of men in crop production can also be attributed to the use of new technologies in farming. Studies by Synnevåg and Lambrou (2012) found that female tasks that can become mechanized tend to become male tasks. The increase in milk production and its commercialization has also attracted men who are interested in the profit from the industry.

The role of sikom- a system of communal labour in dealing with increased labour needs - was a possibility years ago. However, this is not possible today, as a shift towards a more market-oriented crop production, especially in the wetter areas of Chepareria, has led to intensification and commoditization of cultivation. With increased commercialization of crop production, timely crop production practices (land preparation, planting and weeding, amongst others) require that individuals pay for such services using cash or other agreeable terms (Wernersson 2013). In contrast, sikom was mainly used for various tasks that were deemed too demanding for an individual household. As such, this communal labour system was common during the establishment of enclosures, specifically to address labour needs for fencing (live or dead tree branches) and the preparation of terraces for soil and water conservation (Makokha et al. 1999). As this labour system worked on a rotational basis within the community, individuals were only supposed to provide meals which were served to sikom participants and family members. However, with the increased daily household duties and tasks due to the continuous establishment of enclosures, an increase in casual labour was reported. With time, it has become more common to employ someone to help out at home with both traditionally male and female tasks such as cleaning, cooking, fencing and digging. The need for this additional labour has furthermore increased as the school-going children are not around anymore to help during the daytime like before. Also, women who are 
particularly successful with their income-generating activities have less time to spend with the household chores. All this means that there are increased opportunities even for women with no or little education or access to financial means to earn a steady income as maids.

Poultry production is another enterprise which is viewed as one which can be practised even by the poor and vulnerable in the community, owing to its low startup costs and its rapid payback period (ASDSP West Pokot CCU 2013). Increased recognition of the poultry value chain as a key but undervalued contributor to household livelihood security has given more scope to the enterprise. Poultrykeeping has mainly been seen as a female entrepreneurial activity since it was adapted by the traditionally pastoralist Pokot. However, men are continually getting involved as middle-men as the business continues to gain ground in acceptance and practice. Increasing productivity in the local poultry value chain could largely contribute to further elevating even marginalized women's economic power.

Mixed perceptions exist on the overall changes in the responsibilities of men. Many female respondents felt that the men's tasks and overall work burden have decreased significantly while men reiterate that their roles have only increased with the evolution of enclosures and reduced livestock migration needs. These sentiments are true, depending on the context from which one decides to look at it. From a male perspective, their responsibilities have increased due to the fencing needs, as both boundary and paddock fence maintenance need to be done regularly. However, from a female perspective, enclosure establishment and proper fence maintenance have significantly reduced herding needs, as animals can be let out to graze in pasture paddocks with little or no herding.

\section{Relationship between enclosures and changing gender roles}

It is a fact that most interventions to eradicate poverty either directly or indirectly affect or are affected by gender dynamics. Besides poverty alleviation, the role of gender dynamics is essential in environment and common property regimes (FAO 2003). The overarching point here lies in the fact that both environmental degradation and the disappearance of common property regimes are core issues for poor households, particularly women and children in the rangelands (Gaani et al. 2002). While water shortage and firewood is a quandary for both men and women, the burden is particularly severe on women, since in almost every dryland culture, they are tasked with water and firewood collection.

The establishment of enclosures has had significant impacts for the people of Chepareria in West Pokot, both at the household level as well as more broadly on society and lifestyle (Karmebäck 2015). Besides restoring formerly degraded lands, fostering ecological change and diverse environmental benefits and and improving standards of living, traditional gender roles have also changed (Wairore et al. 2015a). Sedentary lifestyles facilitated by enclosures and the connected growth of the entrepreneurial scene locally are fostering stronger ties not only by keeping families together for longer periods but also by facilitating increased communication between men and women, particularly when it comes to decisionmaking. While findings from other studies under the Triple L Initiative have shown that men and women have different spheres of responsibilities within the household and within the local economy (Wernersson 2013; Saxer 2014; Karmebäck 2015), we reiterate that these boundaries are becoming less defined. This study finds that in Chepareria, both men and women are increasingly seeing the contemporary family unit as a team that needs to work together on meeting the household's needs, and women have thereby in large received increased decision-making power. Women are increasingly engaged in responsibilities that have traditionally been male responsibilities, and - albeit to a lesser extent - the opposite is true, too. As this paper has shown, this is due to a number of factors, mainly an evolving entrepreneurial scene locally and drastic changes in the household economy, both of which are closely connected to the spread of private enclosures in Chepareria, as well as improved access to the formal education system, which has impacted the local economy in various ways.

Land inheritance amongst women is slowly but surely taking root in Chepareria partly due to the recognition of women rights as enshrined in Kenya's New Constitution, the Land Act 2012 (Kenyalaw.org 2012a) and the Land Registration Act 2012 (Kenyalaw.org 2012b). Due to women's crucial role in poverty alleviation and food security, it is not surprising that NGOs are looking to support and empower women in Chepareria (Wernersson 2013). However, in other patriarchal cultures, women's participation in decision-making on enclosure management is fairly limited, as a result of various cultural and social factors, as observed by Nedessa et al. (2005) in Ethiopia. While supporting and empowering women in drylands is crucial, this must be done with care by constantly re-examining the gender boundaries to ensure that identity "inside" and support therein is not lost as described by Wernersson (2013). This is imperative since studies in Somalia by Kandagor (Kandagor 2005. Rethinking pastoralism and African development: A case study of the Horn of Africa, unpublished) have shown that men can feel threatened by female empowerment. As such, gender awareness in the conceptualization and planning stages of environmental management approaches in gender-segregated and patriarchal societies will remain 
critical in improving the management of enclosed areas, participation in decision-making and ultimately livelihood security of dryland communities.

\section{Conclusion}

Despite men and women in Chepareria still having different spheres of responsibilities and positions within the household economy as well as with regard to public life, the boundaries are becoming less defined. This is closely linked to the fact that the local economy has evolved greatly in the past few decades, an evolution that has been both directly and indirectly impacted by the establishment of enclosures in the area. Both men and women are now increasingly involved in entrepreneurial activities, partly due to increased household monetary needs, and the creation of a local and reliable output market for basic food items. With the overall increased commodification of agriculture and entrepreneurial activity locally, casual employment has become more common, opening up opportunities for income generation even for marginalized and uneducated people. All of this points to a promising development not only towards a higher degree of gender inclusivity in Chepareria but also towards inclusivity of formerly marginalized and thereby disadvantaged sections of society.

Overall, women are now increasingly seen as crucial income earners and their position in society is on the whole elevated. They are enjoying a higher degree of financial independence, more decision-making power and a louder voice than before in household and public matters. The traditional gender roles are in a constant state of change and will continue to evolve and develop. As mentioned earlier in this paper, the County Government of West Pokot in its County Integrated Development Plan 2013 to 2017 identifies gender inequality as a major challenge in the county. The Development Plan states that most women are confined to household chores and are mostly not involved in decision-making committees, however, our findings show that this is evolving. With the various ecological and socio-economic developments taking place in the Cheparerian community, the boundaries of male and female spheres and responsibilities are expected to become less and less defined over time. This will in turn bring with it further challenges and changes, but above all opportunities for the people of West Pokot.

\section{Competing interests}

The authors declare that they have no competing interests.

\section{Authors' contributions}

VK and JW carried out the field studies upon which this paper is based. VK took lead in preparing the initial as well as the revised draft, and VK and JW were responsible for most of the writing. GN and $\mathrm{MJ}$ reviewed and commented. GN initiated the studies. All authors have read and approved the final manuscript.

\section{Author details}

${ }^{1}$ Triple L Research Initiative - Land, Livestock and Livelihood Dynamics (www.TripleL.se), Department of Forest Ecology and Management, Swedish University of Agricultural Sciences, Umeå, Sweden. ${ }^{2}$ Department of Land Resource Management and Agricultural Technology (LARMAT), University of Nairobi, Nairobi, Kenya. 'Department of Human Geography, Lund University, Lund, Sweden. ${ }^{4}$ Department of Forest Ecology and Management, Swedish University of Agricultural Sciences (SLU), Umeå, Sweden. ${ }^{5}$ Fröslövsvägen 543-16, 27176 Löderup, Sweden.

Received: 20 March 2015 Accepted: 21 September 2015

Published online: 09 November 2015

\section{References}

Angassa, A., and G. Oba. 2008. Herder perceptions on impacts of range enclosures, crop farming, fire ban and bush encroachment on the rangelands of Borana, Southern Ethiopia. Human Ecology 36: 201-215.

Angassa, A., and G. Oba. 2010. Effects of grazing pressure, age of enclosures and seasonality on bush cover dynamics and vegetation composition in southern Ethiopia. Journal of Arid Environments 74: 111-120.

ASDSP West Pokot CCU. 2013. Local chicken value chain analysis. Government of Kenya Agriculture Sector Development Support Programme (ASDSP), West Pokot County. Team Leader: V.M. Namboka, VCDO. October 2013.

Awino Ochieng, Jl, and VN Karmebäck. 2014a. Linking Vi-Agroforestry Data with the Triple L Initiative. Working Report, Jan. 2014.

Awino Ochieng, Jl, and VN Karmebäck. 2014b. Understanding change in West Pokot County and explaining its drivers. A study under the Triple L Initiative: Land, Livestock and Livelihood Dynamics- Uncovering the transition towards sedentary livestock based agro-pastoralism in semi-arid East Africa.

Awumbila, M., and J.H. Momsen. 1995. Gender and the environment: Women's time use as a measure of environmental change. Global Environmental Change 5(4): 337-346.

Beyene, F. 2009. Exploring incentives for rangeland enclosures among pastoral and agropastoral households in eastern Ethiopia. Global Environmental Change 19: 494-502.

Beyene, F. 2010. Locating the adverse effects of rangeland enclosure among herders in eastern Ethiopia. Land Use Policy 27: 480-488.

Catley, A., J. Lind, and I. Scoones (eds.). 2013. Pathways to sustainability: Pastoralism and development in Africa. Earthscan from Routledge. Abingdon: Dynamic Change at the Margins.

County Government of West Pokot. 2013. First County Integrated Development Plan 2013-2017. Available at: http://www.westpokot.go.ke/images/ downloads/CIDPfinaldraft.pdf. Accessed on December $8^{\text {th }}, 2014$.

FAO. 2003. Gender and sustainable development in drylands: An analysis of field experiences. Rome: FAO.

Flintan, F. 2011. SUMMARY BRIEF: The causes, processes and impacts of land 577 fragmentation in the rangelands of Ethiopia, Kenya and Uganda. Available at: http://www.preventionweb.net/files/24288_ 24288summarybrieflandfragmentationf.pdf. Accessed 30 November 2014.

Gaani, MX, CY Axmed, MC Kille, MJ Ibraahim, CM Axmed, and X Ibraahim. 2002. Regulating the livestock economy of Somaliland. Somaliland (Draft Only): Academy for Peace and Development Hargeysa.

IFAD (International Fund for Agricultural Development). 2006. Gender and desertification: Expanding roles for women to restore drylands. Rome, Italy: IFAD.

Karmebäck, VN. 2015. Narratives of shifts in gender roles. Diversified livestock based agro-pastoralism in drylands. A study under the Triple L Initiative.

Kenyalaw.org. 2012a. The Land Act, 2012.No. 6 of 2012.Law of Kenya. Available at: www.kenyalaw.org. Accessed 30 November 2014.

Kenyalaw.org. 2012b. The Land Registration Act, 2012.No. 3 of 2012, Law of Kenya. Available at: www.Kenyalaw.org. Accessed 30 November 2014.

Kitalyi, A., Musili, A., Suazo, J., and Ogutu, F. 2002. Enclosures to protect and conserve. For better livelihood of the West Pokot community. Regional Land Management Unit (RELMA). TECHNICAL PAMPHLET No. 2. Available at: www.samsamwater.com/library/TP2_Enclosures.pdf. Accessed 10 August 2015.

KNBS (Kenya National Bureau of Statistics). 2009. West Pokot District Development plan 2008-2012.

Lastarria-Cornhiel, S. 1997. Impact of privatization on gender and property rights in Africa. World Development 25(8): 1317-1333.

Lesorogol, C.K. 2008. Land privatization and pastoralist well-being in Kenya. Development and Change 39(2): 309-331. 
Makokha, W, S Lonyakou, M Nyang, KK Kareko, C Holding, TJ Njoka, and A Kitalyi. 1999. We work together: Land rehabilitation and household dynamics in Chepareria Division, West Pokot District, Kenya. RELMA Technical Report No. 22, 81. Nairobi Kenya: RELMA/SIDA. ISBN 9966-896-42-2.

McDermott, J., S. Staal, H. Freeman, M. Herrero, and J. Van de Steeg. 2010. Sustaining intensification of smallholder livestock systems in the tropics. Livestock Science 130: 95-109.

Mekuria, W., E. Veldkamp, M. Tilahun, and R. Olschewski. 2011. Economic valuation of land restoration: The case of exclosures established on communal grazing lands in Tigray, Ethiopia. Land Degradation \& Development 22(3): 334-344. doi:10.1002/ldr.1001.

Messer, N.M. 2001. "Mapping traditional structures to inform decentralisation policies: Illustrations from three countries in Sub-Saharan Africa and the Near East", Household Livelihood Strategies and Local Institutions Working Paper No. 12. Rome: Food and Agriculture Organization of the United Nations.

Mureithi, SM, A Verdoodt, and E Van Ranst. 2010. Implications of enclosures for rehabilitating degraded semi-arid rangelands: A review of critical lessons from Lake Baringo Basin, Kenya. Land degradation and desertification: assessment, mitigation and remediation, Zdruli P et al. (eds.) Springer Dordrecht: Heidelberg London New York, 490 pp. 111-130. doi: 10.1007/978-90-481-8657-0.

Napier, A, and S Desta. 2011. Review of pastoral rangeland enclosures in Ethiopia. Feinsteain International Centre and Tufts University, November 2011, Addis Abeba. http://fic.tufts.edu/assets/Tufts-Range-Enclosure-Review-PLI.pdf.

NDMA (National Drought Management Authority). 2014. Drought Early Warning Bulletin - West Pokot County. National Drought Management Authority: Drought Monthly Bulletin for May 2014.

Nedessa, B, J Ali, and I Nyborg. 2005. Exploring ecological and socio-economic issues for the improvement of area enclosure management: A case study from Ethiopia. Drylands Coordination Group Report No. 38 (05, 2005).

Said, MY, L Ng'ang'a, G Nyberg, S Kifugo, W Wredle, A Hallmén, R Waiganjo, P Mwangi, L Jan De, and P Ericksen. 2014. Measuring resilience-Understanding trends in land cover changes and their potential impacts on pastoral communities. Addis Ababa, Ethiopia: IFPRI 2020 Conference on "Building Resilience for Food and Nutrition Security". May 15-17, 2014.

Saxer, L. 2014. A changing land tenure system and its social implications: The case of land enclosure processes in Chepareria, West Pokot, Kenya. MSc Thesis, University of Gothenburg.

Synnevåg, G, and J Lambrou. 2012. Climate-smart agriculture: Possible roles of agricultural experimenting with compensation for pastoralists subject to the sub-division of land in Kenya: Kitengela case study. Nairobi: A case study for IUCN-WISP

Verdoodt, A., S.M. Mureithi, L. Ye, and E. Van Ranst. 2009. Chronosequence analysis of two enclosure management strategies in degraded rangeland of semi-arid Kenya. Agriculture, Ecosystems and Environment 129(1-3): 332-339.

Verdoodt, A., S.M. Mureithi, and L. Ye Van Ranst. 2010. Impacts of management and enclosure age on recovery of the herbaceous rangeland vegetation in semi-arid Kenya. Journal of Arid Environments 74: 1066-1073.

Verma, R. 2001. Gender, land and livelihoods in East Africa: Through farmers' eyes. Ottawa: IDRC

Wairore, J.N. 2015. Enclosing the Commons: A new paradigm in the management of East African drylands.. Available at: http://www.researchgate.net/ publication/281032764. Accessed 19 October 2015.

Wairore, JN, SM Mureithi, OV Wasonga, and G Nyberg. 2015a. Benefits derived from rehabilitating a degraded semi-arid rangeland in private enclosures in West Pokot County, Kenya. Land Degrad. Develop., doi: 10.1002/ldr.2420.

Wairore JN, SM Mureithi, OV Wasonga, and G Nyberg. 2015b. Characterization of enclosure management regimes and factors influencing their choice among agropastoralists in North-Western Kenya. Pastoralism: Research, Policy and Practice, 5(1), 14. doi: 10.1186/s13570-015-0036-7.

Wernersson, JEV. 2013. Towards a critical social theory of landscape: Perceptions and experiences of land-use change in Chepareria, Kenya. Master Thesis in Master Programme in Global Studies, University of Gothenburg.

Westermann, O., J. Ashby, and J. Pretty. 2005. Gender and social capital: the importance of gender differences for the maturity and effectiveness of natural resource management groups. World Development 33(11): 1783-99.

WFPNAM Kenya. 2005. World Food Programme Vulnerability Analysis and Mapping.

Woodhouse, P. 2003. African enclosures: A default mode of development. World Development 31(10): 1705-1720.

\section{Submit your manuscript to a SpringerOpen ${ }^{\circ}$ journal and benefit from:}

- Convenient online submission

- Rigorous peer review

- Immediate publication on acceptance

- Open access: articles freely available online

- High visibility within the field

- Retaining the copyright to your article

Submit your next manuscript at springeropen.com 